\title{
EFFECT OF ADDING ORGANIC ACID TO DIET IN SOME EGG QUALITY AND INTESTINAL ENVIRONMENT FOR QUAIL
}

Ghadeer Abd Al menam Mohamed Alrahawi

\author{
Department of Animal Production, College of Agriculture and Forestry, University \\ of Mosul \\ Email :ghadeerabd3011985@yahoo.com
}

\begin{abstract}
This study was conducted on quail to investigate the effects of some organic acids on egg qualities characters, enteric ecosystem and reproductive performance. One hundred eightybirds were reared from 1 day to 42 days of age, distributed to 3 treatments, (three replicates, 20 birds / replicate) $.1^{\text {ST }}$ treatment (control) reared on standard ration, $2^{\text {nd }}$ treatment reared on standard ration supplemented with Lactic acid (2.5 mg / kg ration), $3^{\text {rd }}$ treatment reared on standard ration supplemented with Citric acid (2.5 mg / kg ration). Statistical analysis of data showed that the addition of Organic acid improves significantly $(\mathrm{P} \leq 0.05)$ egg weight, albumen weight, yolk weight, height of albumen, high of yolk, yolk diameter, egg length, shape index, weight of first egg, age oflaying 50\% egg laying intensity, weight of male reproductive system and length of oviduct as compared with control treatment . No significantly effects in yolk index, egg width, shell weight, shell thickness and internal shell membranes. Significant decrease in Salmonella and E.Coli. Significant increase in Lactobacillus content and significant increase in Lymphocyte $\%$ in male and females quail, in Hetrophils and Esinophils in females treated with Organic acid . Improved $\mathrm{H} / \mathrm{L}$ ratio in Organic acid treatment as compared with control, andsignificant decreased $(\mathrm{P} \leq 0.05)$ in Coagulation timeand Cholesterol concentration in $2^{\text {nd }}$ and $3^{\text {rd }}$ treatment; In conclusion, organic acids improved the enteric ecosystem, egg quality and reproductive performances .
\end{abstract}

Key words: organic acid, bird quail, performance physiology , number bacteria .

Received: 9/1/2018, Accepted: 16/5/2019

\section{INTRODUCTION}

One of the new challenges in the poultry industry is to search for natural additions to water and food to improve the efficiency of poultry especially when the European Union preventin (2006) the usage of antibiotics as growth promoter. The researchers began to attention to use alternative methods to improve the performance of poultry, including medical herbs, yeast and organic acids because of their effects in promoting the growth of beneficial bacteria and eliminate harmful bacteria and improve feed efficiencyand the health of poultry Khosravi ,et al (2010). Organic acids have been widely accepted as an alternative to antibiotics in poultry production, where it was observed when addition of organic acids to drinking water reduce the level of pathogens and improve digestion also improved growth (Philipsen, 2006). Organic acids were a short chain volatile fatty acids, most of which have been used to prevent the growth of microbes in feed it has been proven that it can be used in animal and poultry production as an effective and safe alternative to the antibiotics to stimulate growth, sustain immunity and prevent the 
infection of many intestinal diseases, it been used as additives in feed or drinking water, the use of organic acids intensively in recent years has contributed to inhibiting the growth of harmful bacteria such as Salmonella in feedmaterialsused in fodder mixtures Radicliffe (2000) . Organic acids and their salt have been used as safe sources . This study was designed to determine the effect of the addition of some organic acids (Acetic and Lactic) to the quail ration in the egg quality and some enteric micro flora .

\section{MATERIALS AND METHODS}

The study was conducted in the poultry field Department of Animal Production / College of Agriculture and Frosty /University of Mosul for the period 1/May/2018 to $21 / \mathrm{June} / 2018$, birds were reared with dimensions of $50 \times 50 \times 50 \mathrm{Cm}$ and provided with all the necessary management indices. The study continues from one day to the age of 42 days.One hundred eighty birds divided to 3 treatment, with 3 replicates for each (20 birds/replicate), T1(control)rearedon a standard ration, T2 reared on standard ration supplemented with (2.5 gm Lactic $/ \mathrm{kg}$ ration), $\mathrm{T} 3$ on standard ration supplemented with (2.5 gm Acetic acid/kg ration). The prepared onstandard ration were compound according to (N.R.C. 1994), table (1).

Table (1): The components of the ration used in the study

\begin{tabular}{|c|c|c|}
\hline Ingredients & Growth ration \% & Productive ration \% \\
\hline Yellow corn & 50 & 40 \\
\hline Wheat & - & 21 \\
\hline Proteins Conentrate & 15 & 10 \\
\hline Soybean Meal & 31 & 22 \\
\hline Sun flower oil & 3 & 2 \\
\hline Calcium & 0.9 & 4.5 \\
\hline Salt & 0.1 & 0.5 \\
\hline Total & 100 & 100 \\
\hline Protein Ratio & 24.04 & 20.16 \\
\hline $\begin{array}{c}\text { Calculated energy kg / } \\
\text { kg }\end{array}$ & 2992.8 & 2841.6 \\
\hline
\end{tabular}

N.R.C (1994)

When the birds reached the age of egg production the following parameters were calculated :Egg quality ,10 eggs from each replicate, weighed and broken to calculates, height albumin, yolk height, yolk dimension, yolk weight, shell thicken, shell weight, shape index, yolk index . age of puberty, and weight of first egg and age of reach to $50 \%$ egg production .At the end of treatments, 12 birds from each treatment were slaughtered for the measurement of Oviduct, Ovary weight, length Oviduct, and estimate microbialcontent of intestines from bacteria E.Coli , Salmonella and Lactobacillus by method Harriganand McCance(1976). Blood samples were collected in heparinized tubes, smears were prepared for leukocytes count Campbell,(1995), also blood were collected in a plain tubes, then serum collected for. measurementConcentration of Cholesterol using kit (Biolabo, Maizy , France) and the time of clotting time using plain capillary tubes. The statistical 
analysis was performed completelyrandomized design (C.R.D)one way analysis of variance differences between totals were determined using Duncan's Multiple Ranges test (Duncan , 1955) for all the measurement studied and level of statistical characterize was $(\mathrm{P} \leq 0.05)$ as described by (Steel and Torri(1960) using SAS (2001) . program to analyses the data and using the following equation :

$\mathrm{Yij}=\mu+\mathrm{ti}+\mathrm{eij}$.

Yij = Value of observation in the observation in the experimental .

$\mu=$ the general average .

ti $=$ effect of treat .

eij $=$ effect of the experimental error .

\section{RESULT AND DISCUSSION}

The resultsshowed in table (2) a significant increase in egg weight, albumin weight, yolk weight, albumin height, yolk height, egg length and shape index in T2 (lactic acid) and T3 (acetic acid) compared with control treatment at $\mathrm{P} \leq 0.05$,nonsignificant difference in yolk index, shell weight, shell thickness and internal shell membranes for all treatments. These results were agreed with the result ofALTamimi and AlZuhairi(2016) when addition of lactic acid and acetic acid caused significant increase in the albumenheight, yolk heightand yolk dimension . results also agreed with Kaya, et al (2014) showed asignificant difference in yolk height and yolk diameter when he add acetic acid to the quail ration, result, not agreed with Alp et al (1999). Theimprovemention eggquality may be due to enhancement of albumin secretion from magnum so that the albumin weight and egg weight were increase significantly AL-Mashaekhly and Naji(1990).The results may be according to a positive correlation between the egg size and yolk size and the increase an egg size which cause increase in yolk dimension, resulting an increase in the yolk dimension of the egg AL-Fayadh and Naji(1989) . For the results were similar ALTamimi and AL-Zuhairi (2016) the results of the statistical analysis showed no significant different during production periods, also agreed with the finding of Kaya and Gul(2014) and also a result agreed with Soltan (2008) and Kaya and Gul (2015) there were no significant in shell weigh . While the results were not agreed AL-Tamimi and AL-Zuhairi (2016) where they pointed to significant in weight shell egg .

Table (3) revealed that quail ration of lactic acid and acetic acid caused a significant increase in the weight of $1^{\text {st }}$ egg respectively compared with control at $\mathrm{P} \leq 0.05$, also the treatments reduce significantly the age of $1^{\text {st }}$ egg laying (puberty) for lactic acid and acetic acid treatment compared with control, as well as a significant decrease in the interval (age) to reach 50\% of egg production for lactic acid and acetic acid treatments compared with control . 
Table (2): Effect of organic acid treatments on egg weight and egg quality

\begin{tabular}{|c|c|c|c|}
\hline Treatment & $\begin{array}{c}\text { Control } \\
\text { pareatment }\end{array}$ & Lactic acid (2.5\%) & $\begin{array}{c}\text { Acetic acid } \\
(2.5 \%)\end{array}$ \\
\hline Egg weight $(\mathrm{gm})$ & $11.00 \pm 0.25 \mathrm{~b}$ & $14.33 \pm 0.36 \mathrm{a}$ & $13.50 \pm 0.22 \mathrm{a}$ \\
\hline Albumenweight $(\mathrm{gm})$ & $5.02 \pm 0.24 \mathrm{~b}$ & $6.28 \pm 0.16 \mathrm{a}$ & $6.34 \pm 0.40 \mathrm{a}$ \\
\hline Albumen height $(\mathrm{mm})$ & $3.96 \pm 0.16 \mathrm{~b}$ & $4.84 \pm 0.24 \mathrm{a}$ & $4.89 \pm 0.25 \mathrm{a}$ \\
\hline Yolkweight $(\mathrm{gm})$ & $3.29 \pm 0.09 \mathrm{~b}$ & $3.94 \pm 0.12 \mathrm{a}$ & $4.15 \pm 0.19 \mathrm{a}$ \\
\hline Yolkheight $(\mathrm{mm})$ & $9.29 \pm 0.24 \mathrm{~b}$ & $10.67 \pm 0.11 \mathrm{a}$ & $10.30 \pm 0.81 \mathrm{a}$ \\
\hline Yolk diameter $(\mathrm{mm})$ & $20.81 \pm 0.09 \mathrm{~b}$ & $23.99 \pm 0.45 \mathrm{a}$ & $24.43 \pm 0.40 \mathrm{a}$ \\
\hline Egg Length $(\mathrm{cm})$ & $31.83 \pm 0.36 \mathrm{~b}$ & $33.98 \pm 0.69 \mathrm{a}$ & $34.08 \pm 0.61 \mathrm{a}$ \\
\hline Egg width $(\mathrm{cm})$ & $25.53 \pm 0.07 \mathrm{a}$ & $24.35 \pm 0.36 \mathrm{a}$ & $24.78 \pm 0.22 \mathrm{a}$ \\
\hline Shell weight $(\mathrm{gm})$ & $1.66 \pm 0.19 \mathrm{a}$ & $1.86 \pm 0.89 \mathrm{a}$ & $1.64 \pm 0.02 \mathrm{a}$ \\
\hline Shell thicken $(\mathrm{mm})$ & $0.29 \pm 0.04 \mathrm{a}$ & $0.25 \pm 0.01 \mathrm{a}$ & $0.23 \pm 0.01 \mathrm{a}$ \\
\hline $\begin{array}{c}\text { Internal shell thicken } \\
\text { (mm) }\end{array}$ & $0.02 \pm 0.004 \mathrm{a}$ & $0.02 \pm 0.002 \mathrm{a}$ & $0.02 \pm 0.003 \mathrm{a}$ \\
\hline Shape index & $1.24 \pm 0.01 \mathrm{~b}$ & $1.34 \pm 0.02 \mathrm{a}$ & $1.37 \pm 0.02 \mathrm{a}$ \\
\hline Yolk index & $0.44 \pm 0.01 \mathrm{a}$ & $0.44 \pm 0.01 \mathrm{a}$ & $0.42 \pm 0.006 \mathrm{a}$ \\
\hline
\end{tabular}

The values withdifferent horizontal letters indicate significant differences at the $(\mathrm{p}<0.05)$.

Table (4) showed that quail ration supplementation with lactic acid and acetic acid improve the enteric ecosystem of the birds as represented in the significant reduction in the Salmonella and E.coli count in intestinal content and the significant increase in lactobacillus count as compared with control.

Table (3): Effect of organic acid treatments on weight of first egg, age at first egg laying intensity and age of $50 \%$ of production

\begin{tabular}{|c|c|c|c|}
\hline Preatment & $\begin{array}{c}1^{\text {st }} \text { egg weight } \\
(\mathrm{gm})\end{array}$ & $\begin{array}{c}\text { age of first egg } \\
\text { laying (day) }\end{array}$ & $\begin{array}{c}\text { Age of } 50 \% \\
\text { production } \\
\text { (day) }\end{array}$ \\
\hline Control treatment & $9.66 \pm 0.66 \mathrm{~b}$ & $39.00 \pm 0.75 \mathrm{a}$ & $43.33 \pm 0.88 \mathrm{a}$ \\
\hline Lactic acid $(2.5 \%)$ & $13.66 \pm 0.33 \mathrm{a}$ & $35.66 \pm 0.88 \mathrm{~b}$ & $41.33 \pm 0.57 \mathrm{~b}$ \\
\hline Acetic acid $(2.5 \%)$ & $13.62 \pm 0.35 \mathrm{a}$ & $36.66 \pm 0.33 \mathrm{~b}$ & $40.66 \pm 1.20 \mathrm{~b}$ \\
\hline
\end{tabular}

The values with differentvertically letters indicate significant differences at the $(\mathrm{p}<0.05)$.

These results agreed with the finding of Ali and AL-naimee (2006) where they showed significant decrease in the rate of the number of coliform bacteria when adding lactic and acetic acid compared with control treatment, results were in agreement with Line, et, al (1997) when add acetic and lactic acid in drinking water, and Mustafa et ,al (2014) where found significant increase in number lactobacillus bacteria when adding (1\% and $2 \%$ acetic acids in drinking water compared with control treatment, While the addition of acetic acid caused significant decrease in number E.Coli bacteria and enterococcus compared with control treatment .This is due to the lower $\mathrm{pH}$ of intestine approach 6 which works to increased the inhibition of pathogenic bacteria such as Salmonella and E.Coli, the reason for the low numbers of bacteria is due to the ability of organic acids to 
pended rate the wall of harmful bacteria and eliminate them, Peter theobald (2016), When reduce $\mathrm{pH}$ bacteria in digestive by the influence of organic acid to the wall of bacteria do the inhibits natural physiological function Gauthier (2002) . The increase in lactobacillus bacteria is due to the fact that bacterial are active in the acidic medium as opposed to harmful bacteria these are consistent with the results (Al-Kassi and Mohsen, 2009) .

Table (4) :Effect of organic acid treatments on some intestinal micro flora of quail

\begin{tabular}{|c|c|c|c|}
\hline Parameters & Salmonella & E.Coli & Lactobacillus \\
Treatment & & & \\
\hline Control treatment & $16.83 \times 10^{4} \pm 0.70 \mathrm{a}$ & $14.66 \times 10^{4} \pm 1.20 \mathrm{a}$ & $13.33 \times 10^{4} \pm 1.40 \mathrm{~b}$ \\
\hline Lactic acid $(2.5 \%)$ & $12.33 \times 10^{4} \pm 0.49 \mathrm{~b}$ & $11.83 \times 10^{4} \pm 0.47 \mathrm{~b}$ & $19.83 \times 10^{4} \pm 1.86 \mathrm{a}$ \\
\hline Acetic acid $(2.5 \%)$ & $11.66 \times 10^{4} \pm 0.88 \mathrm{~b}$ & $11.33 \times 10^{4} \pm 0.99 \mathrm{~b}$ & $17.16 \times 10^{4} \pm 1.37 \mathrm{a}$ \\
\hline
\end{tabular}

The values with different vertically letters indicate significant differences at the $(\mathrm{p}<0.05)$.

Table (5) revealed that quail ration of lactic acid and acetic acid caused a significant increase in the relative weight of right testis and weight of left testis with lactic acid and acetic acid compared with control, also the treatments increase significantly the length of oviduct compared with control treatment . No significant differences in ovary weight and oviduct weight .

Table (5): Effect of organic acid treatments on relative weight of parts of male and female reproductive system and length of Oviduct

\begin{tabular}{|c|c|c|c|}
\hline Treatment & $\begin{array}{c}\text { Control } \\
\text { treatment }\end{array}$ & Lactic acid (2.5\%) & $\begin{array}{c}\text { Acetic acid (2.5 } \\
\%)\end{array}$ \\
\hline $\begin{array}{c}\text { Parameters } \\
\text { weight reproductive } \\
\text { system\% }\end{array}$ & $3.81 \pm 0.35 \mathrm{a}$ & $4.47 \pm 0.42 \mathrm{a}$ & $3.90 \pm 0.12 \mathrm{a}$ \\
\hline weight Ovary\% & $2.01 \pm 0.19 \mathrm{a}$ & $2.40 \pm 0.1 \mathrm{a}$ & $2.20 \pm 0.08 \mathrm{a}$ \\
\hline weight Oviduct\% & $1.80 \pm 0.20 \mathrm{a}$ & $2.07 \pm 0.29 \mathrm{a}$ & $1.70 \pm 0.08 \mathrm{a}$ \\
\hline Length Oviduct (Cm) & $29.95 \pm 0.55 \mathrm{~b}$ & $33.75 \mathrm{v} 0.47 \mathrm{a}$ & $32.75 \pm 0.4 \mathrm{a}$ \\
\hline weight right testis\% & $1.49 \pm 0.14 \mathrm{~b}$ & $1.86 \pm 0.08 \mathrm{a}$ & $1.87 \pm 0.11 \mathrm{a}$ \\
\hline weight left testis\% & $1.38 \pm 0.11 \mathrm{~b}$ & $1.90 \pm 0.05 \mathrm{a}$ & $1.61 \pm 0.14 \mathrm{a}$ \\
\hline
\end{tabular}

The values with different horizontal letters indicate significant differences at the $(\mathrm{p}<0.05)$

Table (6) showed that quail ration supplementation with lactic acid a significant increase in relative Lymphocytes cell for male and female acetic compared with the male and female control treatment. No significant differences showed between treatment in relative hetrophilecells, esimophil cells, basophil for male and female . Significant increase in \% monocyte cells for male in acetic and lactic acid and in lactic acid in female . Significant decrease in hetrophile cell in acetic and lactic acid as compared with control and decrease in monocyte cell in female in acetic acid treatment significant decrease in esinophil cell in female of lactic and acetic acid treatment. $\mathrm{L} / \mathrm{H}$ ratio decrease in female and male in acetic and lactic acid as compared with control. This was accompanied by a significant decrease $\mathrm{H} / \mathrm{L}$ ration and enhancing physiological performance Houshmandet,al (2012). The results agreed with research Yusuf et,al (2016) where it was found that the addition of 
organic acids lead to differences in the Lymphocytes and Hetrophils ration and ration $\mathrm{H} / \mathrm{L}$ compared with the control treatment .

Table (6): Effect of organic acid treatments on the differential count of white blood cells

\begin{tabular}{|c|c|c|c|c|}
\hline $\begin{array}{c}\text { Treatment } \\
\text { parameters }\end{array}$ & Sex & $\begin{array}{c}\text { Control } \\
\text { treatment }\end{array}$ & Lactic $\operatorname{acid}(2.5 \%)$ & $\begin{array}{c}\text { Acetic acid } \\
(2.5 \%)\end{array}$ \\
\hline \multirow[t]{2}{*}{ \% Lymphocyte } & Female & $72.00 \pm 1.08 \mathrm{~b}$ & $77.50 \pm 0.95 \mathrm{a}$ & $79.50 \pm 0.50 a$ \\
\hline & Male & $75,00 \pm 1.58 \mathrm{~b}$ & $81.00 \pm 0.70 a$ & $78.75 \pm 0.94 a$ \\
\hline \multirow{2}{*}{$\%$ Hetrophile } & Female & $16.00 \pm 1.08 \mathrm{a}$ & $12.50 \pm 0.74 b$ & $13.00 \pm 0.40 \mathrm{~b}$ \\
\hline & Male & $12.50 \pm 1.04 \mathrm{a}$ & $10.25 \pm 0.94 \mathrm{a}$ & $12.50 \pm 0.64 \mathrm{a}$ \\
\hline \multirow[t]{2}{*}{$\%$ Monocyte } & Female & $6.75 \pm 0.47 \mathrm{a}$ & $7.00 \pm 0.70 \mathrm{a}$ & $4.50 \pm 0.50 \mathrm{~b}$ \\
\hline & Male & $7.50 \pm 0.64 \mathrm{~b}$ & $4.75 \pm 0.64 \mathrm{~b}$ & $4.75 \pm 0.40 \mathrm{a}$ \\
\hline \multirow[t]{2}{*}{ \% Esinophil } & Female & $4.50 \pm 0.95 \mathrm{a}$ & $2.25 \pm 0.47 \mathrm{~b}$ & $2.75 \pm 0.62 \mathrm{~b}$ \\
\hline & Male & $4.25 \pm 0.85 \mathrm{a}$ & $3.00 \pm 0.81 \mathrm{a}$ & $3.25 \pm 0.25 \mathrm{a}$ \\
\hline \multirow[t]{2}{*}{ \%Basophile } & Female & $0.75 \pm 0.25 \mathrm{a}$ & $0.75 \pm 0.25 \mathrm{a}$ & $0.25 \mathrm{v} 0.25 \mathrm{a}$ \\
\hline & Male & $0.75 \pm 0.25 \mathrm{a}$ & $0.75 \pm 0.25 \mathrm{a}$ & $0.50 \pm 0.28 \mathrm{a}$ \\
\hline \multirow[t]{2}{*}{$\mathrm{H} / \mathrm{L}$ ratio } & Female & $0.222 \pm 0.01 \mathrm{a}$ & $0.158 \pm 0.006 \mathrm{~b}$ & $\begin{array}{c}0.166 \pm 0.006 \\
b\end{array}$ \\
\hline & Male & $0.170 \pm 0.01 \mathrm{a}$ & $0.125 \pm 0.01 b$ & $\begin{array}{c}0.175 \pm 0.008 \\
\mathrm{ab}\end{array}$ \\
\hline
\end{tabular}

The values with different horizontal letters indicate significant differences at the $(\mathrm{p}<0.05)$.

Table (7) showed significant decrease in cholesterol concentration of lactic and acetic acid treatments as compared with control. Acetic acid treatment caused to significant decrease in coagulation time compared with control treatment, but no significant differences between lactic and control treatments .

[Table (7): Effect of organic acid treatments on Concentration of Cholesterol and Coagulation time of quail ]

\begin{tabular}{|c|c|c|c|}
\hline Treatment & Control treatment & Lactic acid (2.5\%) & Acetic acid (2.5\%) \\
\hline $\begin{array}{c}\text { Parameters } \\
\text { Cholesterol } \\
(\mathrm{mg} / \mathrm{dl})\end{array}$ & $191.443 \pm 3.71 \mathrm{a}$ & $152.069 \pm 4.77 \mathrm{c}$ & $168.021 \pm 4.55 \mathrm{~b}$ \\
\hline $\begin{array}{c}\text { Coagulation time } \\
\text { (second) }\end{array}$ & $32.50 \pm 1.36 \mathrm{a}$ & $28.83 \pm 1.88 \mathrm{ab}$ & $26.66 \pm 2.10 \mathrm{~b}$ \\
\hline
\end{tabular}

The values with different horizontal letters indicate significant differences at the $(\mathrm{p}<0.05)$. 
تأثثر إضافة الأحماض العضوية إلى العليقة في بعض الصفات النوعية للبيضة وبيئة الأمعاء لطائر السمان

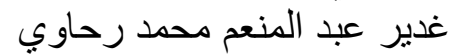

قسم الإنتاج الحيواني، كلية الزراعة والغابات / جامعة الموصل، الموصل، العراق

Email :ghadeerabd3011985@yahoo.com

\section{الخلاصة}

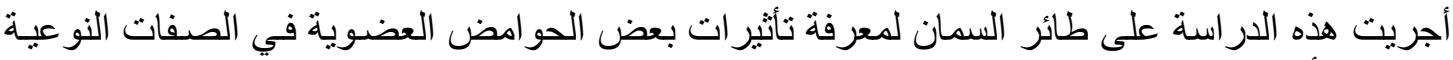

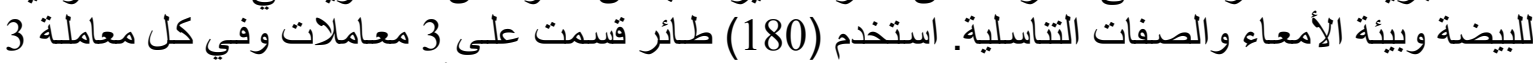

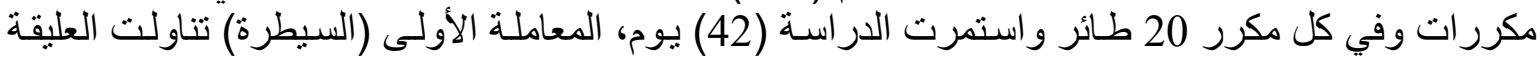

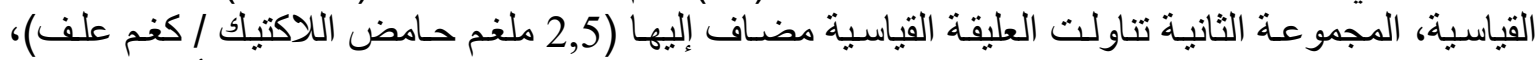

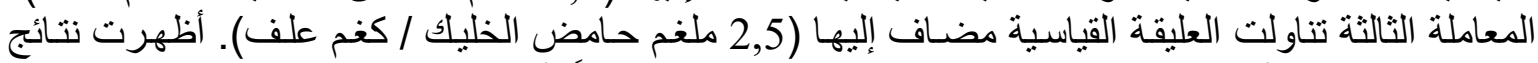

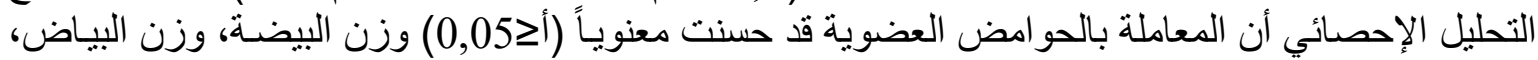

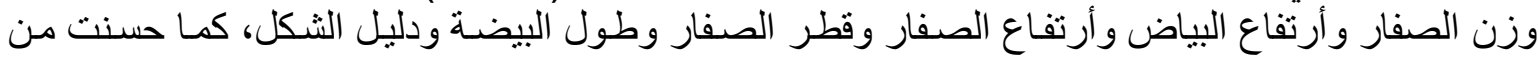

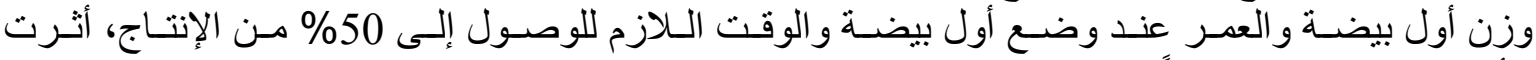

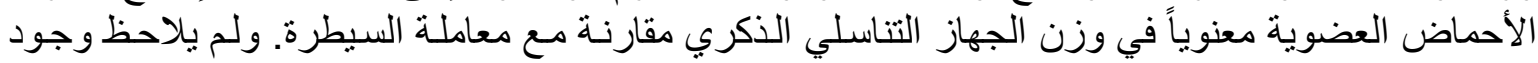

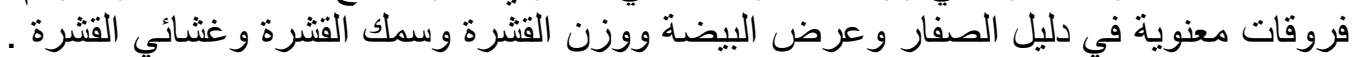

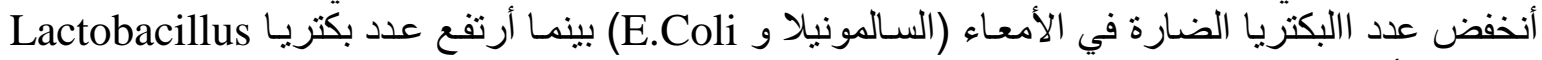

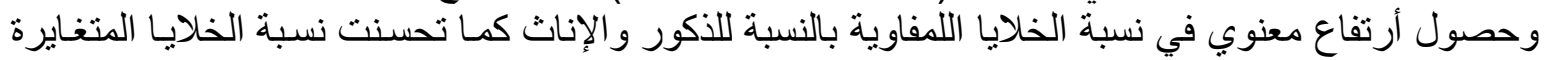

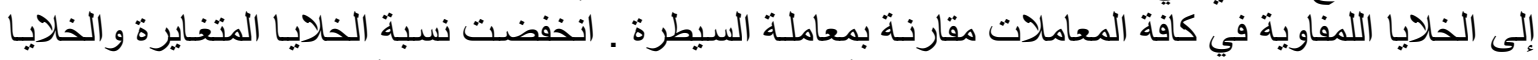

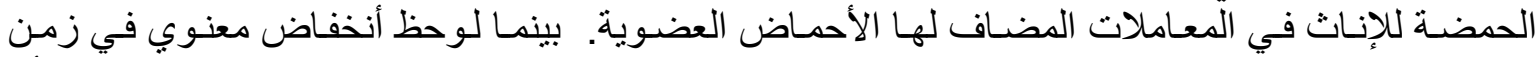

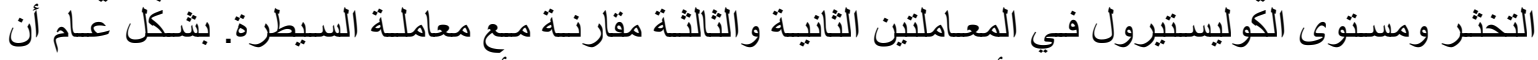

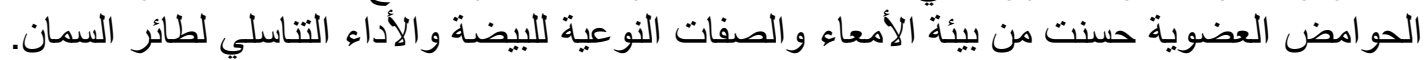





\section{REFERENCE}

Al-Fayahd .Hamdi Abdel Aziz and Saad, Abdul Hussein Naji . (1989) .Poultry Products Technology .first edition . Directorate of higher education. Baghdad - Iraq .626.

Ali , M. S. BahaaEldin , Alnaimee , M. I. A. . (2006) . Effect of adding organic acids in drinking water in production performance and intestinal intestines of broilers and sensory characteristics of carcasses .Tikrit University Journal of Agriculture Sciences , 6 (3) .

AL-Kassi.A.G and Mohsen,M,A. 2009 . Comparative study between single organic acid effect and synergistic organic acid effect on broiler Performance . Pakistan Journal of nutrition . 8(6)896-899.

Al-Mashakhly ,ShaalanAlwan and NajiSaad Abdul Hussein . (1990) .Chemistry And Technology Egg . Faculty of Agriculture . Baghdad University. Ministry of high education and Scientific research .241 .

Alp,M.; Kocabagli, N. and Kahraman,R. (1999) . Effect of dietary supplementation with organic acids and zinc-bacitracin on olealmicroflora, $\mathrm{PH}$ and performance in broiler. Journal of Veterinary and Animal Science , 23:451455 .

Al-Tamimi ,AmmarTalebDiab and Al-Zuhairi, Mohamed Adel Hassan . (2016) . Effect of adding two levels of Lactic acid and Acetic acid to the diet in some 
qualities of egg quality and preparation of intestinal bacteria for chicken . Basra Journal of Agricultural Sciences . 29 (2) . 391 - 404 .

Campbell,T.W.(1995) . Avian Hematology and Cytology. Second edition , MS, DVM. PhD. Lowa State press .Ablackwell Publishing Company .

Duncun , D.B.(1955). Multiple and multiple F test biometrics . 11: 1-42 .

Gauthier . R., (2002). Intestinal health the key to productivity (The case of organic acids) XXVII Convencion ANECA-WPDSA Puerto Vallarta ,Jal . Mexico . 30 April 2002.

Harrigan , N . F ., and M. F. McCance.(1976) . Laboratory Methods in food and Dairy Microbiology Academic press .London .

Houshmand,M., Azhar, K.,Zulkifli, I., Bejo,M., and Kamyab,A. (2012) . Effect of probiotic, protein level, and stocking density on performance, immunity , and stress indicators of broilers . Poultry Science, 91, $393-401$.

Kaya , A. and Gul,M. (2014) . Effects of supplementation of different levels of organic acids mixture to the diet on performance, egg quality parameters, serum traits and histological criteria of laying hens. Europe. Poult.Scie., 78:14-20 .

Kaya, A. and Gul,M. (2015) . Effects of different levels of organic acids mixture to the diet of hens on laying performance, egg quality criteria, blood parameters , and intestinal histomorphology . Indian J. Anim. Res. 49 (5) : 645 - 651.

Khosravi,A.,Boldaji,F.,Dastar,B. and Hasani,S., 2010 . Immune Response and performance of Broiler Chicks Fed Protexin and Propionic Acid. International Journal of Poultry Science 9(2):188-191 .

Line,J.E.,J.S.Bailey,N.A.Cox, and N.J.Stern, 1997. Yeast treatment to reduce salmonella and campylobacter Population associated with broiler chicken subject to transport stress . Poultry Sci. 76:1227-13, 1 .

Mustaff,M.A.GH . Sulaiman,M.Salahaddin,L .2014 . Effect of acetic acid added to drinking water of two Broiler Strains on Performance and Small Intestine Histological .Diyala Agricultural Scie.J.6(1)1-8 .

National Research Council, (NRC), (1994) . Nutrient Requirements of Poultry. 9th Ed., National Academy Press, Washington DC, USA.

Peter Theobald .2016 . Principles of using organic acids in animal nutrition .Nurtingen-GeislingenUniversity, Germany . 175 pp .

Philipsen,I.P.L.J 2006.Acidifying drinking water supports performance . World Poult. 22:20-21 .

RadicliffeJ .2000 . British supermarkets: Forging changes in Poultry nutrition . Australian Poultry Science Symposium 12,25-31 .

SAS. (2001) . SAS / STAT User's Guide for Personal Computers . Release 6.12. SAS Institute Inc Cary Nc, U.S.A.

Soltan , M.A.(2008) . Effect of dietary organic acid supplementation on egg production, egg quality and some blood serum parameters in laying hens . International Journal of Poultry Science, 7(6):613-621 .

Steel , R. G. D. and J. H. Torrie (1960) . Principles and Procedures of Statistics . McGraw - Hill Book . Co., Ine, New York, N. Y. 481 PP. 
Mesopotamia J. of Agric.

Vol. (47) No. (2) 2019
ISSN: 2224 - 9796 (Online)

ISSN: 1815 - $316 \mathrm{X}$ (Print)
مجلـــة زر اعــة الـر افديـن المجلد (47) العدد (2) 2019

Yusuf ,M.S ., Ibrahim ,M.T., Samy ,H.M., Mahmoud , M.M.A. (2016) .Yeast , Lactose, and Organic Acids Mixture Improved Zoological growth and Immune Status of Japanese quails . Biological Forum - An International Journal . 8(1):255-267 . 